\title{
A EDUCAÇÃO PELA IMAGEM \& OUTRAS MIRAGENS
}

EDUCATION THROUGH IMAGES AND OTHER MIRAGES

André Bueno 1

Resumo Este ensaio analisa as formas contemporâneas do capitalismo, voltando-se para as miragens postas pela sociedade do espetáculo e os simulacros de massa, assim como para as vertentes culturalistas, relativistas e populistas do pensamento pós-moderno, mostrando como essas variações em torno da cegueira enfraquecem a tradição crítica acumulada pelas gerações anteriores, no Brasil e no mundo.

Palavras-chave capitalismo; pós-modernidade; educação e trabalho.
Abstract This essay analyses the contemporary forms of capitalism, turning to the mirages put forward by the entertainment industry and by the mass images as well as to the culturalist, relativist and populist streams of post-modern thought. We will attempt to show how these variations on the theme of blindness weaken the critical tradition built by previous generations in Brazil and in the world.

Key words capitalism; post-modernity; education and work. 
No livro VII da República, Platão utiliza uma alegoria, o mito da caverna, para explicar sua teoria do conhecimento. Mostra como somos prisioneiros do mundo sensível, das imagens, dos simulacros e das sombras do que parece ser a verdade, vivendo na escuridão e na ignorância. Através de uma dialética ascendente, indica como é possível sair da escuridão para a luz, da cegueira para o conhecimento, passando do mundo sensível ao inteligível. Processo difícil e doloroso, pois aquele que sai da caverna fica deslumbrado pelo excesso de luz e não sabe, a princípio, distinguir o que é a realidade, se esta dimensão iluminada ou a conhecida escuridão da caverna, onde os prisioneiros vivem de sombras, de imagens, de simulacros, de opiniões repetidas sem crítica.

O segundo movimento descrito por Platão é o de uma dialética descendente. Aquele que teve acesso ao mundo inteligível volta e tenta convencer os cegos da caverna de que existe uma outra realidade. O resultado, como se sabe, é desanimador, pois aquele que viu a luz da verdade já não se sente à vontade no mundo das sombras, não consegue convencer os cegos e tornase motivo de chacota, correndo o risco de ser morto.

Em resumo, o mito da caverna ilustra uma teoria do conhecimento baseada nos movimentos de uma dialética ascendente e descendente, difícil e dolorosa, tanto para quem se eleva, quanto para os que ficam presos às sombras e simulacros projetados na parede. Assim, a dialética platônica é uma forma de libertação e iluminação, separando o verdadeiro do falso, a aparência da essência, as ilusões do mundo sensível, da opinião corrente, e o conhecimento racional, construído e refletido. Como se sabe, a dialética platônica terá uma longa fortuna crítica, e o mito da caverna atravessa os séculos como uma alegoria muito sugestiva sobre a condição humana, seus limites e possibilidades de conhecimento.

Sirva como exemplo o último livro de José Saramago, intitulado justamente A caverna (2000), parte de uma trilogia que se completa com o Ensaio sobre a cegueira (1996) e Todos os nomes (1997). Trilogia que pode ser lida e entendida como uma crítica, muito elaborada, da crise contemporânea da condição humana no capitalismo avançado. Após uma série de romances que fazem uma revisão da História de Portugal, como Memorial do Convento, $O$ Ano da Morte de Ricardo Reis e História do Cerco de Lisboa, Saramago voltase para problemas mais gerais, que se deslocam dos contextos nacionais e regionais. Assim, o cenário da trilogia poderia ser qualquer cidade da nossa época, com sua opacidade e estranheza, com a forma impessoal que lhe dá o próprio capitalismo em expansão.

Mas, em que sentido Saramago retoma em seu livro o mito da caverna? Certamente não o faz no sentido idealista, de um conhecimento puro do bem, do bom e do verdadeiro, separado das aparências, imagens, simulacros e, ainda por cima, livre de tudo que forma a doxa, a opinião corrente e irre- 
fletida, na qual os personagens vivem mergulhados. Pode-se dizer que a narrativa de Saramago põe em movimento as vidas e os impasses de pessoas comuns - o oleiro Cipriano Algor, sua filha Marta, seu genro Marçal Gacho, a viúva Isaura -, fazendo-as mover-se entre campo e cidade, artesanato e indústria, trabalho manual e trabalho mecânico, valores de uso - ligados aos objetos de barro - e valores abstratos de troca - ligados ao mundo do grande Centro de Compras, que absorve tudo a seu redor. Nesse Centro de Compras, onde se podem encontrar simulacros de quase tudo, civilizações e florestas, batalhas e eventos históricos de todo tipo, como uma espécie de catálogo vazio, de enumeração fantástica e sem contexto, é encontrada a própria Caverna de Platão. O desfecho é previsível, dentro da lógica da narrativa: sem qualquer força crítica, isenta de memória ou espessura histórica, incapaz de qualquer dialética, ascendente ou descendente, a Caverna de Platão torna-se apenas também um simulacro, mais uma atração, mercadoria entre mercadorias, a ser vendida no Centro de Compras.

No livro de Saramago, pode-se falar, com justiça, de vida na caverna pósmoderna, mergulhada o tempo todo em simulacros, em imagens e imagens da mercadoria, a se repetir em um presente veloz, vazio e voraz, do qual se ausentaram as vidas e a memória das gerações passadas. E pode-se também entender a atualidade da citação que abre o livro, tirada do Livro VII da República: "Que estranha cena descreves e que estranhos prisioneiros. São iguais a nós".

Dizer vida na caverna pós-moderna equivale a dizer vida nas sociedades urbanas do capitalismo avançado, apontando para a própria forma da crise da condição humana na época em que estamos vivendo. É sinônimo de uma cegueira muito profunda, pessoal e coletiva, que Saramago aborda no Ensaio sobre a cegueira, mostrando como são frágeis os limites que separam civilização e barbárie, a aparente naturalidade da vida cotidiana a se repetir e as bruscas alterações que levam os personagens - os supostos cidadãos - à degradação, à infâmia, à bestialidade. Acometidos por uma cegueira branca, de todo alegórica, os personagens são excluídos da cidade, confinados, retornando a um estado quase que de horda primitiva. Voltam à cidade, caminham pelas ruas, passam pelas praças onde se vendem milagres e maravilhas, por fim enxergam de novo. Mas, sabemos no final do livro, cegos estavam e, restituídos à visão, cegos continuaram.

Como o leitor há de notar, posições que vão a contrapelo da cultura pósmoderna, que faz o elogio das superfícies, das imagens, dos simulacros, dos fragmentos soltos da vida social, da simples imersão nas aparências cotidianas da vida urbana. E o faz como um valor, algo a ser defendido e enfatizado, em termos de abertura, pluralidade, deriva, intensidade, instalando, com um passe de mágica, o reino da liberdade em pleno reino da necessidade. Mais do que isto, pondo de lado o reino da necessidade e as inúmeras resistências 
do real, tornando a própria necessidade uma virtude. Em resumo, a vida na caverna pós-moderna não como experiência empobrecida e mutilada, desumanização e violência, redução do campo do possível, o mundo do máximo fetiche da mercadoria, das coisas conversando com outras coisas, mas como o campo para inúmeras escolhas, vários estilos de vida a serem consumidos.

A crítica de Saramago, feita pelo ângulo materialista, não supõe que possa existir um mundo de idéias puras para onde deveríamos ascender, nem tampouco imagina uma ascese religiosa, que nos retirasse da miséria do mundo e da morte do corpo, apontando para algum tipo de transcendência. A crítica fica no campo imanente, indicando a necessidade de pensar e criticar, justamente, as formas da vida na caverna pós-moderna. Vale dizer, os simulacros, os ídolos da tribo, a cegueira, o senso comum e a doxa, enfim, tudo o que dá a forma do capitalismo e da condição humana em nossa época. O que supõe um outro tipo de dialética, por ora emperrada em seu momento negativo e sem superação do existente à vista. Ou seja, na passagem do século XX para o XXI, vivemos o ponto mais baixo de uma longa dialética da derrota, em que os mais altos projetos de emancipação humana também entraram em crise, a filosofia não foi realizada na História, o céu não foi tomado de assalto e não se entrou em uma etapa superior de civilização. A síntese mais forte poderia ser, apenas para refrescar a memória, que a democracia sem o socialismo não pode ser democracia, assim como o socialismo sem democracia não pode ser socialismo.

Vale lembrar um outro exemplo de retomada do mito da caverna platônico em nossa época. Está no livro em que Fredric Jameson (1991) relaciona a cultura pós-moderna e a lógica do capitalismo tardio, o conhecido Postmodernism or the cultural logic of late capitalism (Pós-modernismo ou a lógica cultural do capitalismo tardio). Ou avançado, tanto faz. Aqui também avulta o mundo do simulacro, das imagens de massa, da cultura da imagem atravessando toda a vida cotidiana como característica central da pós-modernidade, acompanhada de uma expansão da esfera cultural para toda a vida social. Temos com isto, uma vez mais, a analogia com os cegos e ignorantes da caverna platônica, incapazes de conhecer outra realidade que os fantasmas e sombras projetados nas paredes de sua caverna, onde consomem imagens e mercadorias, como membros de uma pólis apenas virtual, definida pela mão invisível do mercado. Pior do que isso, a crer na análise de Jameson, condenados a não ter mesmo acesso a nenhuma realidade, exceto fragmentos, pastiches, representações esvaziadas de força crítica. Sem sequer o sonho de uma outra coisa, de uma outra educação, de algum outro tipo de formação, diferente desse longo discurso da servidão voluntária, da passividade sedutora, do gosto pela imersão sem conflitos nos mitos e mentiras da época.

Como tudo mais que dá forma à crise contemporânea do capitalismo, a cultura pós-moderna não pode ser posta de lado, pois é inseparável do que 
Guy Debord (1992) chamou sociedade do espetáculo. Não como crítica dos meios de comunicação, como alguns fazem hoje em dia, mas como percepção aguda do fetiche da mercadoria em escala mundial, tornando tudo imagem e espetáculo, abolindo os valores de uso e deixando à mostra apenas a superfície vazia do valor de troca. Ou seja, um mundo sem memória, espessura histórica, densidade emocional, conflitos e contradições, apagando, de tudo, o valor social do trabalho e a educação como trabalho que possam formar o cidadão crítico e seletivo. Na expressão do próprio Debord (1997), a imagem tornou-se a forma final do fetiche da mercadoria. Daí o sentido do presente como um lugar vazio e veloz, que apenas se repete, uma vasta coleção de imagens que a tudo absorve e recupera, exibido como espetáculo e mercadoria. Vale dizer, simulacros e superfícies que englobam tudo - economia, política, trabalho, lazer, arte, religião, educação, violência, abolindo a distância que separa o público do privado. Por esse ângulo, a crítica das posições pós-modernas fica mais aguda e exigente, trazendo à tona características que precisam ser pensadas com cuidado, caso se queira tomar distância da doxa que define o sentido de nossa época.

Pensada apenas como crítica dos meios de comunicação, a sociedade do espetáculo deixa de ser a forma mais forte do capitalismo avançado, uma expansão da indústria da cultura, como a pensaram Adorno e Horkheimer em seu exílio nos Estados Unidos durante a Segunda Guerra, inseparável de uma administração e colonização da vida pública e privada, no trabalho e no lazer, dissolvendo o indivíduo em aparatos que não podem ser controlados, muitas vezes nem mesmo entendidos. Não se trata, portanto, de discutir se a tecnologia dos meios de massa é boa ou ruim, se o suporte livro vai ser substituído pelo suporte virtual das redes mundiais de computadores, e coisas do tipo, tentando situar os avançados e os retrógrados, os eufóricos e os fóbicos diante das novas tecnologias. Trata-se de entender os profundos efeitos desse processo expansivo do capitalismo e das tecnologias na vida cotidiana - em relação ao trabalho, à educação, à saude, ao lazer, à cultura, à própria organização da vida social e histórica. Como problema de fundo, temos um conflito muito marcante, opondo civilização e barbárie. Querendo com isso dizer que o capitalismo é um sistema cego quanto a valores coletivos e contratos sociais democráticos, podendo muito bem conviver com as formas mais ou menos liberais e com as mais declaradas ditaduras, desde que sua expansão seja garantida. Indo um pouco além, cabe uma crítica do progresso e dos mitos da modernização, das promessas de felicidade que o capitalismo vai criando, sem poder cumprir.

As formas da cegueira contemporânea, como indicadas nos exemplos que abrem este ensaio, passam todas por essa cegueira sistêmica e estrutural, que não pode ser resolvida com boas intenções, boa vontade, consciências culpadas ou movimentos filantrópicos. Fiquem como exemplo os que se ves- 
tem de branco e vão às ruas pedir paz, sem criticar o sistema que não cessa de produzir e reproduzir a violência que ocupa o cotidiano de nossas cidades. Ou pior, dos que se dedicam à filantropia, destinando as sobras da mesa da Casa Grande aos pobres, como se isso pudesse trazê-los para uma vida civilizada e protegida da violência e da exclusão.

Acontece que o capitalismo avançado vai de par com o ponto mais baixo de uma já longa dialética da derrota dos movimentos revolucionários, que saíram do horizonte histórico de maneira marcante. Como se não bastasse, a revanche do capital contra o trabalho também vai levando de roldão os direitos conquistados em décadas de lutas, que deram a forma do Estado do BemEstar Social como expressão de um capitalismo mais ou menos domado em seus aspectos predatórios e selvagens. Inúmeras análises, consistentes e coerentes, mostram os resultados negativos dessas derrotas conjugadas no mundo do trabalho e da vida cotidiana das cidades. Enfraquecida a esfera dos direitos e das garantias civilizatórias - ligadas ao trabalho, à segurança, à saúde, à educação, à moradia, à cultura -, instala-se uma forma muito aguda de darwinismo social, de luta de todos contra todos, como competição cega que vai passando por eufemismos como os de progresso, modernização e qualidade total nas empresas, tomadas agora como modelo único da vida em sociedade. As linhas de força do processo são conhecidas, mas precisam ser aqui lembradas: empregos instáveis ou temporários; terceirização dos serviços; exigência de qualificações múltiplas e flexíveis para o mesmo nível salarial; diminuição constante da renda dos que trabalham; níveis crescentes de desemprego. Na lógica mundial dos mercados, cabe à periferia a mão de obra barata e precária, deixando os centros de poder e administração nos países centrais, acentuando a distância que separa o Norte e o Sul do planeta. De quebra, defende-se uma presença mínima do Estado no mercado e na vida social, o que significa, para países periféricos como o nosso, abdicar de políticas públicas e de um projeto nacional que seja mais do que mera inserção subalterna na ordem mundial do capitalismo.

Como nunca tivemos aqui um Estado do Bem-Estar Social, apenas uma sociedade colonial escravocrata que transita para uma República elitista e autoritária, fazendo a miséria migrar do campo para a cidade, a violência desse processo é constante. A figura do horror econômico, das determinações da economia capitalista ocupando todas as esferas da vida social - expressão cunhada por Viviane Forrester (1997) a partir de uma imagem de Rimbaud - resume bem o problema, bem como sua extensão e profundidade. Não é preciso ser muito perspicaz para perceber os efeitos nocivos, para a saúde física e emocional dos trabalhadores, da conjugação aguda de todos esses fatores negativos, e a pesquisa mais séria e exigente não cansa de mostrar como isso é verdade.

Com isso, os sentidos humanos continuam sendo educados para a integração, a aceitação do existente, a luta direta pela sobrevivência na selva das 
cidades, não para o acesso a formas superiores de civilização e vida em sociedade. Vale lembrar que a introdução acelerada de novas tecnologias, alterando em profundidade o mundo do trabalho, não tem sido de jeito nenhum seguida por uma diminuição no tempo de trabalho e um conseqüente aumento do tempo livre para atividades que se pudesse chamar criativas, autônomas e livres de coerção.

Não se cumpriu a previsão de Aristóteles, que imaginou o dia em que as rocas fiassem sozinhas, deixando aos humanos tempo e energia para expandir suas capacidades e talentos. Na sociedade do espetáculo em escala mundial, o tempo é cada vez mais controlado, diminuindo muito, ou quase abolindo, a distância que separa trabalho e lazer. Nos casos mais avançados, por exemplo das grandes corporações norte-americanas, tudo é planejado no sentido de conseguir do trabalhador uma adesão total, irrestrita, com traços mesmo de culto religioso, aos valores e à "cultura da empresa", de fato anulando a distância que separa trabalho e lazer. Em resumo, trabalha-se mais, em empregos instáveis e precários, o valor dos salários diminui, e os direitos diminuem ou são simplesmente abolidos. Com toda a certeza, vale tudo por dinheiro, mas por estas portas a esperança nunca passará.

Quanto à defesa da velocidade e da mobilidade trazidas pelas novas tecnologias e sua aplicação ao mundo do trabalho, cabem alguns comentários. Pode-se começar pela idéia de que as cidades, como as conhecemos ao longo da História moderna, deixaram de ter fronteiras físicas, tornando-se apenas espaços virtuais. Isto é verdade para as chamadas cidades globais, que concentram uma forte quantidade de capitais, investimentos, tecnologias, serviços comerciais e administrativos, funcionando como pólos articulados no sistema-mundo que é o capitalismo avançado. Também é verdade para a velocidade com que circulam os capitais voláteis e as informações nas redes mundiais de computadores, promovendo uma integração muito veloz.

Porém, nada disto é verdade quando se pensa o mundo em que vive a maioria dos que trabalham nas cidades e em suas periferias. Os capitais e a informação viajam à velocidade na luz, mas a maioria dos trabalhadores vivem fixados em suas regiões de origem, movendo-se uma ou outra vez por alguma pressão que os faça migrar ou imigrar. Além disso, os capitais e as informações dos sistemas virtuais não têm mesmo fronteira, integrando-se com facilidade. Para os trabalhadores, porém, as fronteiras continuam muito rígidas e definidas, quer na divisão do espaço urbano, quer na passagem de um país a outro, sobretudo se isso significar a entrada em países avançados, como os Estados Unidos e os da comunidade européia. A violência policial se encarrega de mostrar os limites e as fronteiras para os de baixo.

Quanto ao espaço virtual das redes mundiais de computadores - que surgiram dentro de universidades e tinham, no começo, intenções bastante democráticas - cabe precisar melhor seu lugar. Como notou Ignacio Ramonet 
(2001), está em andamento uma colonização do ciberespaço, vale dizer, um projeto das grandes corporações para controlar a rede mundial de computadores. Significa que a ponta de lança da sociedade do espetáculo, do fetiche da mercadoria, passa por esse macrocentro de compras virtual, não por uma democrática e pacífica integração dos diferentes povos da terra, todos tendo acesso à informação, podendo ser educados da mesma forma. Para desfazer miragens, nada mais útil do que citar dados que permitam situar o problema em um contexto mais preciso. Segundo a própria ONU, apenas $2,4 \%$ da população mundial usavam a Internet em 1999, ficando de fora uns meros 97\%: apenas $0,8 \%$ na América Latina e no Caribe, 0,1\% na África subsaariana, $0,004 \%$ no Sudeste Asiático, sendo que $88 \%$ dos que acessam a Internet vivem em países industrializados e têm um bom nível de renda e escolaridade. Seguindo ainda Ramonet, vale lembrar que o número de computadores em uso no mundo é de mais ou menos 200 milhões, para uma população de 6 bilhões, fazendo com o que o acesso à Internet se restrinja a apenas 3\% da população mundial. Se acrescentarmos que mais da metade dos habitantes da Terra nunca usou um telefone, equipamento indispensável para se ter acesso à Internet, e que o número de analfabetos ou alfabetizados de forma precária é enorme, nas suas línguas locais, para não mencionar o inglês, a língua da Internet, temos um contexto pouco móvel e plural, para dizer o mínimo.

Em resumo, a tecnologia de ponta é acessível para minorias de boa renda e escolaridade, educadas em suas línguas locais e no inglês, vivendo em cidades com bom nível industrial e comercial. Vale dizer, em cidades onde algumas áreas podem ser assim classificadas, para não esquecer a marcante convivência de Primeiro e Terceiro Mundos, tanto nas cidades dos países avançados como nas dos países periféricos. Imaginar que uma educação virtual, conduzida por redes de computadores e televisores, possa ser uma panacéia que supere o atraso e a miséria das populações excluídas é apenas uma miragem, interessada e, para muitos, lucrativa. Situado o problema, não se trata de ser eufórico ou fóbico diante das novas tecnologias, muito menos de negar suas utilidades práticas, que existem, são muitas e não precisam ser ignoradas.

É um traço marcante do pensamento pós-moderno a defesa da diferença e da mistura, de tudo que seja alteridade e hibridismo imaginando um tipo de sujeito que seria sempre plural, mutável, sem identidade fixa, vivendo as ricas oportunidades de um cotidiano que ofereceria uma variedade de escolhas e estilos de vida. Com pompa e circunstância, afirma-se que não há apenas uma cultura e civilização, mas civilizações e culturas diferentes, como se esse plural acaciano dissesse e resolvesse tudo que na História tem sido problema e pesadelo.

Visto assim do alto, temos um cenário ao mesmo tempo liberal e anárquico, quase simpático em suas exigências libertárias abstratas e em seu desejo de estar à vontade em um mundo feito apenas de híbridos e diferenças. 
Como se pode notar, um cenário sem traço de mal-estar na civilização capitalista avançada, sem conflito entre sujeito e sociedade, muito menos entre grupos e classes sociais, considerados coisas do passado, restos inúteis de um Iluminismo apenas coercitivo, com suas exigências críticas, suas ilusões de progresso, de sujeito burguês íntegro e unitário, postos em uma História articulada e com uma finalidade bem definida.

Em uma manobra que chega a ser ingênua, tal o seu idealismo, o pensamento pós-moderno coloca-se contra um sentido crítico de História que articule passado e presente, relacionando a curta e a longa duração, as continuidades e descontinuidades, os grupos e as classes sociais, as regiões e os países, os interesses e os conflitos - em suma, a própria forma complexa e contraditória dos processos históricos e sociais. Tudo é tirado de contexto e tornado apenas linguagem, texto, discurso, imagem, desejo, corpo, deriva e abstrações do tipo. Daí a discutir, com seriedade, o sexo da boneca Barbie, os letreiros dos programas de televisão, as telenovelas como equivalentes a Shakespeare, e o circo eletrônico de massa como efetiva retomada do sentido grego e democrático da pólis grega, é só um passo. Que é dado, com garbo e altivez. Ensinando-nos que a televisão reúne a democracia, a educação, o lazer e a formação do cidadão no mundo pós-moderno, como no mundo grego da cidade-Estado, que reunia democracia, drama e didática em um mesmo contexto. Imagino que os filósofos gregos se revirem nas tumbas diante dessa paidéia pós-moderna.

Não por acaso, criticam-se, no pensamento pós-moderno, as reduções culturalistas, o relativismo sem peias e uma veia abertamente populista. Diante de tal assalto à razão, a tradição que faz a crítica do capitalismo deveria recuar, envergonhada, como um embaraçoso dinossauro, um resíduo arcaico, exibindo seus maus modos em meio aos cristais e bibelôs pós-modernos. Se a História não tem sentido, aparente ou profundo, se os fragmentos da vida social não podem ser relacionados em um sistema crítico, se tudo acontece ao acaso, fora de contextos que se possam pesquisar, e tentar entender, para que perder tempo com a difícil tarefa de pensar uma totalidade chamada capitalismo, como um sistema-mundo, para lembrar aqui Wallerstein (1983)? Para que lembrar que Marx mostrou como o capitalismo tende sempre à expansão, à ruptura de fronteiras e limites nacionais e regionais, alterando as mais antigas tradições e pondo em contato o que antes permanecia isolado, em um processo ao mesmo tempo positivo e negativo, que mistura e combina tempos históricos diferentes, em ritmos também diferentes, em uma constelação crítica muito complexa e contraditória? Bastaria ignorar que esse processo de expansão mundial do capitalismo chegou a uma etapa avançada, na qual estamos vivendo, afetando todos os níveis da vida social e histórica.

Ao exagerar a ênfase nos traços culturais, deixando de lado as análises contextuais dos outros níveis, por exemplo, da economia e da política, o pen- 
samento pós-moderno perde de vista que a própria História do capitalismo, nos últimos cinco séculos de expansão, não tem feito outra coisa senão promover movimentos e misturas, rompendo tradições, deslocando populações inteiras, provocando movimentos migratórios e imigratórios, pondo em choque culturas e civilizações que viveram por muito tempo mais ou menos isoladas.

A História do capitalismo, como sinônimo de expansão de uma certa Europa para o resto do mundo, inseparável das formas coloniais e imperialistas, destruindo e dominando os "bárbaros" em favor de uma "civilização" superior, no entanto, é apenas uma face da moeda, aquela que se critica e condena, com toda justiça. A outra face é a herança crítica, de valor universal, que resulta dos mesmos séculos em que se foi formando o mundo moderno, agora todo integrado e ocupado. É quase pueril, para não dizer irresponsável, reduzir as lutas pelos direitos fundamentais dos seres humanos à vida, à liberdade, ao trabalho, à segurança, à educação, à cultura, ao lazer criativo, à livre expressão de crenças e opiniões, o que certamente inclui as diferenças étnicas, sexuais e culturais - levadas a cabo por sucessivas gerações, como algo a ser descartado, por inútil e, digamos assim, branco-machoeuropeu-burguês-centrado-racional-iluminista.

Essa tradição crítica, atualizada e posta em situação diante da crise do presente, poderia ser muito útil para se pensar alternativas à miséria do mundo e à força de um sistema que é violento em sua produção e reprodução, para lembrar aqui Pierre Bourdieu. Miséria cujos números dizem muito sobre a relação entre civilização e barbárie que o capitalismo produz e reproduz na população mundial: mais de 850 milhões são analfabetos; quase um bilhão carece de água potável; 2,4 bilhões não dispõem de saneamento básico; cerca de 325 milhões de crianças estão fora das escolas; 11 milhões de crianças morrem até os cinco anos de idade por causas evitáveis, às vezes, a custos baixíssimos; 1,2 bilhão de pessoas vivem com menos de um dólar por dia e mais de 2 bilhões vivem em níveis próximos da pobreza, somando mais da metade da população mundial. Vale lembrar que são números oficiais e conservadores, exibidos à exaustão nas conferências que reúnem os donos do poder mundial, aos quais seria preciso acrescentar os números do desemprego, do subemprego, da violência urbana e no campo, da exploração do trabalho infantil e da persistência, em pleno mundo das maravilhas pós-modernas, das formas de escravidão que existem no mundo do trabalho. É essa a cegueira central do capitalismo, que poderia realizar a utopia, mas não cessa de excluir a maioria de uma vida civilizada.

Sim, a expansão do capitalismo não cessa de produzir misturas e diferenças, mas não na forma idealista e vazia defendida pelo pensamento pósmoderno, com ares de quem põe em pé o ovo de Colombo. A pesquisa séria e consistente mostra - e valha aqui o exemplo de Immanuel Wallerstein - 
que as misturas e as diferenças promovidas pelo capitalismo em movimento, na sua escala sempre mundial, acontecem em contextos que podem ser muito bem precisados e especificados. E que levam em conta a economia, a política, a cultura, o racismo e o mundo do trabalho, mostrando que há uma divisão étnica e sexual na divisão internacional do trabalho, reservando certas profissões e atividades, com maior ou menor renda e poder de mando, para certos tipos de pessoas. E isso diz respeito à antiga divisão entre trabalho manual e trabalho intelectual, entre tipos diferentes de qualificação profissional e diferentes acessos ao mundo do trabalho. Ao invés de hipostasiar o traço cultural, como faz o pensamento pós-moderno, pode-se ter um modelo crítico mais forte e articulado, mostrando as determinações cruzadas e sobrepostas que definem a divisão internacional do trabalho e suas características regionais e nacionais.

Para tanto, a análise precisa combinar várias determinações relevantes, que definem o acesso ao mundo do trabalho, as oportunidades, os níveis de renda, as posições de mando, além dos níveis de escolaridade e vida na divisão social do espaço urbano que o capitalismo promove. Com esse modelo de análise, mais complexo e abrangente, renda, escolaridade, moradia, etnia, sexo, cultura, religião, combinam-se e mostram posições de classe bem definidas. E, caso se queira, trata-se de uma linguagem, um sistema de signos que identificam e localizam os sujeitos na vida social e cotidiana, distinguindo, integrando, excluindo, protegendo, agredindo, através de uma combinação de traços distintivos que passam pela cor, pelo sexo, pela cultura, pela religião, pelas roupas, pelo modo de falar, pela moradia e por aí afora. Mas não como linguagem, discurso, imagens ou signos abstratos, vazios de referência social e histórica. Uma educação de fato crítica pode muito bem passar por aí, ao invés de se render às miragens ligadas à sociedade do espetáculo.

Uma outra característica da crise contemporânea tem muita força e precisa ser pensada. Diz respeito à aceleração, à velocidade, à compressão do espaço-tempo, à supressão da memória e ao esquecimento como formas ativas do conformismo e da aceitação da violência e da injustiça. Essa armadilha da velocidade tem conseqüências para a saúde física e emocional dos habitantes das cidades, submetidos a pressões muito intensas, que agridem o organismo e o equilíbrio afetivo e emocional. Daí não ser exagero associar um certo conjunto de doenças à maneira como se vive nas sociedades urbanas de massa criadas pelo capitalismo.

Aqui, também, a qualidade da vida humana está em desacordo muito acentuado com as exigências postas pelo mundo do trabalho e pelos mitos das novas tecnologias, sempre vendidas como necessárias, inevitáveis, ponto mais avançado de uma noção abstrata e vazia de "progresso". Fiquem como exemplo os japoneses, que literalmente morrem de tanto trabalhar, esgotan- 
do todas as suas energias e capacidades em uma roda-viva que não poderia ser mais cega. Ou os depósitos de mão-de-obra barata, espalhados por países periféricos, montando mercadorias das grandes corporações norte-americanas, onde se tem níveis de exploração e exaustão comparáveis à fase selvagem dos primórdios do capitalismo. Talvez na novilíngua usada por George Orwell em 1984 fosse possível chamar progresso e civilização o que é apenas violência e barbárie.

Ao fazer da História um lugar vazio e veloz, uma coleção de imagens sem espessura e densidade, a sociedade do espetáculo cria uma relação nova, e bastante estranha, entre passado, presente e futuro. Ao invés de uma acumulação crítica - em que se possa aprender com o trabalho das gerações que nos antecederam, formando a partir do presente uma crítica que projete um futuro diferente, que mereça alguma dia o nome de civilização humana emancipada da necessidade e da violência -, temos um girar no vazio, uma sucessão de simulacros a se repetir, em um presente cansativo e monótono. Que faz lembrar Wim Wenders mostrando a exaustão das imagens através de televisores o tempo todo ligados, sem mostrar ou comunicar nada. A nos lembrar que o excesso, a repetição e a velocidade dos estímulos também cegam. Como expressão aguda de uma experiência muito empobrecida. Quem não conhece o passado, sabemos bem, está condenado a repetir seus erros. Quem não entende o presente, por sua vez, está condenado à cegueira, sem chance de projetar um futuro que não seja apenas a reprodução do existente. Se é assim, a armadilha da velocidade posta pelo mundo pós-moderno com tanta intensidade nos deixa a todos muito mal parados. Daí não deriva que se possa, em um gesto, colocar de lado a crise do presente e a sociedade do espetáculo, pois esse mundo de simulacros é uma ilusão inevitável, através da qual é preciso passar. Ir além das aparências, digamos, na formulação mais simples e direta, de acordo com a mais antiga tradição filosófica.

A crer nas posições pós-modernas mais extremadas, fica parecendo que esse mundo de simulacros, cópias de coisa nenhuma, coleção abstrata de fragmentos históricos sem contexto, seria o campo inteiro do real e do possível. Não apenas, vale notar, projeções distorcidas ou invertidas do processo histórico e social, como a crítica da ideologia cansou de mostrar, mas como uma espécie de alienação da alienação, cegueira da cegueira, da qual seria impossível tomar distância.

Por essa via, como pensar um sistema em escala mundial, com muitas determinações, cruzadas e sobrepostas, que relaciona as referências locais e gerais, a mais comum vida de todo dia e os dados complexos de sistemas internacionais de poder, na forma de uma totalidade complexa, contraditória e móvel? Não seria possível, é claro, pois o pensamento pós-moderno tem, no conceito de totalidade, um de seus alvos prediletos e constantes. Identificase totalidade e totalitário como se todo pensamento crítico, sistemático e ar- 
ticulado, fizesse uma espécie de terrorismo, eliminando os dados pontuais e locais, os particulares sensíveis que, de fato, precisam ser preservados da absorção cega em um grande sistema fechado e totalizado, como expressão do falso, não do real. O problema, em perspectiva crítica, seria o seguinte: como manter vivos os particulares sensíveis, os dados e qualidades da experiência mais comum, sem perder de vista o sistema em escala mundial chamado capitalismo? Como, portanto, não descolar os fragmentos da vida cotidiana, deixando-os soltos, vazios e abstratos, livres de coerção e violência, dando um passo que esvazia a crítica do próprio capitalismo? Sabemos que boa parte do pensamento pós-moderno não se dá ao trabalho de elaborar esse caminho, optando pelo idealismo que apenas mergulha na vida fragmentada, à deriva, voltada para as superfícies da experiência urbana. Daí a sensação de irrealidade que deriva desse tipo de posição.

Para evitar equívocos e reduções, cabe precisar o debate. Conforme ensina a boa tradição dialética, a percepção dos fenômenos visíveis e próximos, imediatos, que circulam pela superfície das coisas e ações que ocupam a vida cotidiana é uma dimensão necessária e inevitável das formas históricas e sociais criadas pelo capitalismo. Ou seja, não há como afastar as ilusões dos simulacros de massa do mundo pós-moderno do capitalismo avançado para ter acesso a alguma essência ou verdade que nos aguardaria, intacta, do lado de lá. Vale dizer que os processos de objetivação, alienação e reificação, de opacidade e estranhamento, são dimensões inevitáveis da experiência cotidiana, atravessada e constituída pela ideologia e suas representações, práticas e simbólicas, concretas e imaginárias.

Ao criar e recriar o mundo objetivo e desencantado, pragmático e instrumental, impessoal e sem coração, o capitalismo não pode ser transparente. Se fosse diferente, não haveria alienação, nem reificação, nem fetiche da mercadoria, nem valor de troca como força abstrata e dominante, muito menos a forma-mercadoria ocupando o espaço que ocupa. E, como tratamos da sociedade do espetáculo, nem seria preciso enfatizar o peso do imaginário como uma força que molda as percepções, as opiniões, o comportamento e o sentido do mundo. Imaginário da mercadoria, lembremos, que tem na propaganda sua verdadeira cultura, e que tende ao homogêneo e linear, de jeito nenhum ao plural e aberto, convidando ao feliz convívio de diferentes linguagens, culturas, etnias e visões de mundo. O que está à venda, no mundo todo, são, cada vez mais, imagens, e não diretamente coisas feitas e produzidas por quem trabalha. Estão à venda as marcas das grandes corporações, inseparáveis de estilos de vida que circulam pela vida social e são incorporados ao mundo da mercadoria.

De fato, a urbanização da humanidade, sinônimo dos séculos de expansão do capitalismo, faz o trânsito do campo para a cidade, das tradições orais e populares para o folclore urbano de massas, desenraizando, absorvendo, 
integrando e, no limite, destruindo as diferenças muito específicas que existiram ao longo de séculos e milênios, antes de que o tempo histórico sofresse a aceleração dada pela Revolução Industrial. Isso pode ser verificado através da comparação entre o número de línguas, de culturas e visões de mundo que havia, digamos, no século XVIII, e as que existem hoje, depois de todo o processo de "modernização", de "civilização" contra a "barbárie", de "progresso" versus "atraso" que o capitalismo promoveu ao redor do mundo inteiro. É marcante a redução na variedade do mundo, ao invés de uma feliz expansão de conhecimento e cultura. Pode-se lembrar, a propósito, a imaginação dialética de Walter Benjamin com seu olhar melancólico voltado para os mitos da modernização, do progresso e do tempo linear, percebendo as ruínas e fragmentos deixados à margem pelo cortejo triunfal dos vencedores. Dos que não cessam de vencer, ainda hoje. E vencem ainda mais pela via do esquecimento, uma maneira de matar duas vezes os já vencidos e derrotados nas gerações passadas. Ainda a crer na posição pós-moderna, apenas voltada para o presente vazio, não poderia haver uma História dos vencidos, apenas simulacros e pastiches de uma experiência para sempre perdida.

Que voltaria, ironia das ironias, apenas como literatura e filmes nostálgicos, incapazes de atingir um mínimo que fosse da realidade passada. Sem traços ou vestígios, a memória da experiência vivida pelas gerações passadas se dissolveria na superfície do espetáculo e nas coleções de simulacros vazios de vida e memória.

Isso posto, é preciso que o pensamento crítico considere o mundo visível, das aparências, os próprios simulacros da sociedade do espetáculo. Mas não para neles se deter, aceitando sua lógica de produção e reprodução, como algo inevitável ou pior, criador de liberdade. Uma vez mais, é preciso criticar a passagem, de todo idealista, que transforma a necessidade em virtude, as carências e restrições em mundo plural e aberto. Mas é para trabalhar uma elaboração de outro tipo, uma imaginação crítica e construtiva, capaz de relacionar esse mundo dos simulacros de massa, da própria sociedade do espetáculo, e os níveis mais elaborados de percepção e conhecimento de nossa época. Um outro tipo de imaginação, pode mesmo ser, que aponte para alguma coisa diferente do que existe e se vai reproduzindo. Não como imagens que matam a própria imaginação, à custa de uma exaustiva e monótona repetição, para lembrar aqui Gaston Bachelard. Que fazer ? Talvez começando por duas frases, simples e diretas: Sim, eu me lembro. Não, eu não me esqueci.

Como a Scheerazade das Mil e uma noites, que precisa continuar criando histórias, noite após noite, para sempre e mais um dia, única vitória contra a morte e o esquecimento. Mais: evitando que o esquecimento se ponha a serviço do poder e a História não seja apenas um pesadelo do qual nunca se possa acordar. Mesmo que seja um pesadelo confortável e refrigerado, que nos 
cegue não por falta, mas por excesso de luz, de neon, de imagens, de sinais, de estímulos, de uma velocidade que leva a lugar nenhum. É lá que nós plantaremos a semente da nossa esperança: à margem da margem, na terceira margem do rio, nas ilhas flutuantes, solitárias e solidárias, ora afastando-se, ora aproximando-se dos continentes.

\section{A tradição crítica brasileira}

Mais de uma vez, Antonio Candido e Roberto Schwarz notaram como é frágil o sistema cultural de um país como o Brasil, periférico e dependente, formado em uma tradição colonial e escravista, entrando sempre de maneira enviesada nas linhas de força do mundo moderno. Fragilidade que não é algo esporádico e ocasional, mas um dado estrutural, muito constante ao longo da nossa formação histórica e social. Daí a dificuldade de se conseguir uma acumulação crítica de conhecimento sobre o Brasil, nas mais diversas áreas. E, mais difícil ainda, que essa acumulação passe para a geração seguinte, tenha conseqüência, e possa ser levada adiante.

Acontece que a crise posta pelo capitalismo avançado, na forma de uma velocidade que fragmenta, isola e promove o esquecimento, trabalha ativamente justo contra esse processo de acumulação crítica, que tem seu período mais notável no século XX e certamente passa pelas escolas e universidades públicas. Sem esquecer, é claro, das diversas relações entre trabalhadores, estudantes, intelectuais e religiosos, com suas formas de associação e empenho político, que foram educando e acumulando conhecimento crítico sobre nosso país. Não, frisemos logo, como um nacionalismo estreito, xenófobo e conservador, voltado para a direita e seus mitos patrióticos, ufanistas e autoritários. Mas sim como um já longo processo de conhecimento da formação nacional de um país,o Brasil, e seu lugar no sistema mundial chamado capitalismo.

País que vai se formando, com suas esperanças e derrotas, sempre projetando um futuro que superasse o atraso e nos colocasse em pé de igualdade com os países mais avançados. Como se sabe, isso foi acontecendo mais como promessa, como encenação grotesca, do que como uma real superação do atraso, que integrasse os de baixo, os excluídos, em uma sociedade justa e democrática. Tem acontecido bem o contrário, estamos cansados de saber. O país já está formado, o futuro já chegou, em vários sentidos está mesmo passando ao largo, e a prometida modernização do nosso capitalismo deu no que deu, acesso civilizado em pequena escala, violência e barbárie em grande escala.

No ponto mais agudo da crise, quando mais nos pode ser útil o conhecimento crítico acumulado pelo trabalho das gerações que nos antecederam, entra em cena, justamente, o pensamento pós-moderno, com seu relativismo 
populista, com seu gosto pelo espetáculo, pelo simulacro, pelo presente vazio, pela falta de memória e pela ruptura com a História que nos levasse à média e à longa duração. Com isso, o que parece ser avanço, progresso, entrada no Primeiro Mundo, acesso às maravilhas tecnológicas, atualização das idéias e do debate político e acadêmico, na verdade vai se configurando como um formidável passo atrás, um retrocesso em que perdemos muito e quase nada temos a ganhar. Exceto umas ilusões, bem tolas, de passar da carroça de boi para o carro de Fórmula 1, em uma corrida em que os brasileiros fazemos ora o papel do burro, ora o de carroça, em uma disputa em que não há nenhum interesse em ser um carro de corrida.

Na competição pelas posições no mundo acadêmico, estamos dispensados de ler o que de melhor produziram nossos economistas, historiadores, educadores, sociólogos, geógrafos, cientistas, escritores, poetas, dramaturgos, cineastas, artistas, críticos de cultura, arte e literatura. E, no mesmo passo, convocados a ler aquilo que a academia globalizada, regida pelos Estados Unidos, apresenta como última palavra - do pós-moderno, do multicultural, dos estudos culturais, disso e daquilo, tanto faz. Dizem que a nação, em qualquer de seus sentidos, é coisa do passado. Que as fronteiras são apenas construções imaginárias. Que não interessam mais os dados das culturas locais e regionais, como que dispersos em uma virtualidade vazia, uma geografia de lugar nenhum, como já foi notado. Ao que parece, sem se notar que esse é justo o movimento dos mercados, da mercadoria e seu fetiche em escala mundial, promovendo um máximo de diferenças, de opções, de estilos de vida destinados ao consumidor, bem diferente do pensamento crítico endereçado ao cidadão. Temos, então, uma variedade de estilos de vida para agradar todos os tipos de consumidores, com muita ênfase nas revoltas juvenis, de ontem e anteontem, hoje absorvidas e tornadas marca e mercadoria. É por essa via que os defensores do pós-moderno enxergam um cotidiano plural e aberto. Chega a ser cômico imaginar alguém nos Estados Unidos, na França, na Alemanha ou na Inglaterra levando a sério tais posições, e com isso deixando de lado seus interesses, tradições, heranças, línguas, culturas, problemas e projetos, em todos os campos da atividade histórica e social. Até o manual de auto-ajuda mais banal deveria ensinar que atraso e dependência vão sempre acompanhados de uma notável baixa na auto-estima dos selvagens, mesmo que se vistam e se esmerem em falar como os civilizados, mostrando-se atualizados com a última moda da vida na caverna pós-moderna. Sirva como exemplo a Barra da Tijuca, no Rio de Janeiro, como simulacro pós-moderno de Miami, com direito a cópia da Estátua da Liberdade e um estilo de vida dos mais detestáveis.

Para o Brasil, país periférico e de modernização tardia e desigual, que combina tempos históricos muito diferentes, o problema tem alcance e relevo, não podendo ser apenas deixado de lado. É preciso pensar, a partir do 
presente, a formação de uma sociedade colonial portuguesa nos trópicos, a passagem dessa sociedade escravista para uma sociedade urbana de classes, sempre atravessada pelo conflito, pela contradição e pela violência ocupando a vida cotidiana. Formação que entra no século XXI em uma posição difícil, já que o futuro chegou, a sociedade se modernizou, e as promessas não se cumpriram, ficando no ar o clima de uma construção interrompida de um amanhecer muito longo de uma revolução burguesa incompleta, de uma transição democrática que não se realiza, de uma incapacidade de tornar internos os mecanismos de controle e decisão diante dos avanços do capitalismo. Ou pior, de um capitalismo mundializado que nos coloca entre a nação e a barbárie, entre uma parte avançada da nação que se integra à nova ordem mundial e o resto, que se desintegra e se desagrega, posto à margem como resultado selvagem do primado da competição econômica sobre qualquer processo civilizatório. Como se nota, uma linha crítica profundamente histórica e especificada, ao contrário do pensamento pós-moderno e seus clichês relativistas, que consideram a História, a justiça, a democracia, a liberdade, e a própria verdade, meros constructos discursivos, simples entidades metafísicas, que nos iludiram durante muito tempo e precisariam ser postos de lado.

Uma breve comparação entre o pensamento pós-moderno, nas suas linhas mais gerais, e uma certa tradição crítica brasileira, formada e compartilhada ao longo do século XX, pode ser útil para situar os problemas postos pelo capitalismo avançado e que vai se apresentando como sociedade do espetáculo, do simulacro ou da imagem, a depender da análise. A comparação passa pela educação e pela cultura, pelas diferentes abordagens que se possa ter desses campos sociais e históricos, apontando as miragens que acompanham o desejo de uma simples educação pela imagem, pelo simulacro, pela imersão direta e sem mediações na sociedade urbana de massas fundada no espetáculo da mercadoria. Em resumo, uma certa tendência do pensamento pós-moderno argumenta que o tempo da alfabetização fonética já passou, que os meios de massa fornecem informação suficiente para os receptores, que não é preciso opor espetáculo ao vivo e simulacro, que foram abolidas as diferenças e limites entre os diversos níveis de cultura e, claro, que o contrário disso pertence ao mundo dos críticos ainda modernos, aferrados a alguma " hermenêutica da profundidade". Cujos modelos, apontados por Fredric Jameson (1991) em Postermodernism or the cultural logic of late capitalism, são os seguintes: 1. o dialético, da essência e aparência; 2 o freudiano, do latente e do manifesto; 3. o existencialista, do autêntico e inautêntico; 4 . o lingüístico, do significante e significado.

Não é difícil perceber o alcance dessa linha de pensamento, nem o quanto se opõe à tradição crítica formada e compartilhada no Brasil ao longo do século XX, como uma acumulação nada desprezível de conhecimento sobre o país e, muitas vezes, sobre a América Latina. Pelo ângulo que mais nos inte- 
ressa - o modelo da dialética histórica e materialista -, o prejuízo não poderia ser maior. Pode-se falar em discursos, linguagens, jogos textuais. Pode-se encadear etnia, gênero e classe, mas não se poderia mais situar a classe, a etnia e o gênero sexual na esfera de uma crítica materialista do próprio capitalismo. Afirma-se a total ausência de limites entre os diversos tipos de cultura, fazendo profissão de fé relativista, passando sem mediações do elitismo mais aristocrático para o populismo mais direto e sem nuance, como se fosse um movimento de emancipação diante de cânones rígidos e fechados. Não por acaso, o pensamento pós-moderno não é muito adepto da ironia e da paródia. Se fosse, perceberia o que significa afirmar que não há diferença ou distância que se possa considerar entre Shakespeare e a telenovela, Saramago e Paulo Coelho, Fellini e os videoclipes da MTV, Pixinguinha e a parada de sucessos, Clarice Lispector e Janete Clair, a tradição oral da cultura popular e os programas de auditório na televisão, a música clássica e o muzzak que se ouve no dentista, no elevador ou em uma loja qualquer. Perceberia como esses dados se encaixam, à perfeição, na fragmentação e no consumo de "estilos de vida", estanques, que o capitalismo avançado vende como pluralidade e diferença. De fato, uma análise cuidadosa mostraria que as relações entre as tradições da cultura popular, da cultura letrada e da cultura urbana de massas precisam ser muito bem situadas, evitando-se, com isso, os riscos de correr em uma pista falsa, passando sem mediações do elitismo ao populismo, e vice-versa.

Para isso, não basta o mero mergulho no senso comum da caverna pósmoderna, a aceitação sem crítica da doxa que atravessa a vida cotidiana, deixando para a sociedade do espetáculo a tarefa de educar os cidadãos. Os modelos oferecidos à maioria pela sociedade do espetáculo, todos os dias, são bem claros: consumo, competição, sucesso, misticismo, violência e vulgaridade. Vale lembrar que essa é, muitas vezes, a única realidade "cultural" para seus espectadores. Cabe então a pergunta: como abolir as diferenças entre os níveis de cultura e defender um mundo aberto e plural, quando a maioria das pessoas não teve, não tem, e talvez nunca tenha, acesso aos vários tipos de cultura, com suas diferentes exigências e formas de perceber o mundo e a condição humana? Lembro aqui Georges Snyders (1993), defendendo a alegria na escola e a obra-prima como um direito de todos, uma forma democrática de distribuir o melhor que a humanidade pode produzir. Direito que é inseparável de uma formação escolar seletiva e crítica, feita ao longo dos anos, que toma distância do senso comum e vai educando os sentidos dos alunos. Pois os sentidos humanos são históricos, formados ao longo da história e podem ser educados para perceber e entender muito mais do que apenas sombras e fantasmas projetados nas paredes de uma caverna. E podem ser educados para algo muito mais sutil e elaborado do que os choques, os excessos de luz, de sinais, de estímulos e de velocidade, a própria cegueira da sociedade do espetáculo. 
Relativista, o pensamento pós-moderno vê elitismo em toda distinção crítica que separe e qualifique as diferentes formas da cultura e da arte. Sem mediações, como já indicamos, a ilusão pós-moderna cai direto no populismo. Mas é possível perceber que se trata de um falso problema, uma oposição que confunde e não esclarece os problemas e passagens que o campo da cultura coloca. Livre de coerções críticas, sem ninguém para ditar normas, definir padrões e estabelecer cânones, uma abstração vazia, chamada sujeito pós-moderno, teria à sua disposição todas as formas de arte e de cultura, podendo escolher em completa liberdade. Claro que essa posição é sempre defendida por pessoas que tiveram uma boa educação, acesso às universidades e centros de estudos, às bibliotecas, à cultura erudita e ao conhecimento seletivo. Para os milhões de excluídos desse mesmo mundo, sobrevivendo nos limites da cultura urbana de massas, restaria então renunciar algo que desconhecem, a que nunca tiveram acesso, e que nunca lhes pode dar a formação necessária para pensar esses e outros problemas. Em um passe de mágica, o excluído passa da necessidade à liberdade, sem nunca ter saído da cegueira do senso comum na caverna pós-moderna. E pode confiar sua educação, e a de seus filhos, e a de seus netos, aos programas de auditório, as paradas de sucessos, as telenovelas, as revistas de fofocas, os livros de auto-ajuda, o cinema comercial e outros produtos culturais e artísticos do mesmo tipo. Quando o problema é bem outro: o oposto de uma tradição elitista e aristocrática não é o populismo autoritário da sociedade de massas. Não se trata de trocar algum cânone fechado por um relativismo em que o vale tudo impede distinguir, selecionar e criticar, dando elementos para que os de baixo possam ser formados e educados de maneira democrática. Temos com isso que não é preciso ficar distinguindo, o tempo todo, o alto, o médio e o baixo na arte e na cultura. Nem mesmo precisamos escolher entre o apocalipse e a integração à sociedade do espetáculo. Seria bem mais útil pensar as passagens e os problemas que relacionam os diferentes tipos de cultura, vale dizer, as tradições populares, letradas e urbanas de massa, com suas variações e misturas. Como não se trata de opor elitismo e populismo, melhor mostrar como são formadas e se relacionam as formas culturais e artísticas. Grosso modo, criar as condições para mostrar o que há de bom e de ruim na literatura, na canção popular, no teatro, no cinema, na pintura, na escultura, no artesanato, no cordel, na música dita clássica, na arquitetura, nas artes gráficas, no desenho de humor, nos gibis, e por aí afora.

O que se vai notar, desde logo, é que não existem níveis estanques e separados de arte e de cultura, mas sim trânsitos e passagens, mais ou menos ricos, a depender de cada caso. Impossível não perceber como as tradições populares e as tradições letradas e eruditas dialogam ao longo dos séculos, absorvendo elementos umas das outras, incorporando temas e percepções, mostrando como, de fato, não há fronteiras rígidas entre esses campos. Im- 
possível não perceber, também, como as artes ligadas à reprodução técnica, como a fotografia, o cinema e a canção dialogam com as mesmas tradições populares e eruditas, com resultados que variam, conforme o caso. Podendo ir da simples diluição mercantil - Mondrian vendendo cigarros, por exemplo -, a formas mais elaboradas e ricas em sentido.

Por certo que a imagem faz parte desse tipo de educação, mas não como simulacro de massa, inseparável do mundo da mercadoria. Educar a visão para a pintura, a escultura, a arquitetura e a arte contemporânea é bem diferente, convenhamos, da simples absorção da propaganda. Também é certo que não se defende um mundo puro de formas culturais e artísticas, separado dos interesses materiais, dos financiamentos, dos patrocínios, das verbas, pois tal mundo nunca existiu, já que a produção, a circulação e a recepção da arte e da cultura sempre se dão em contextos históricos e sociais atravessados por interesses e divisões sociais. Mas, enfim, é mais certo ainda que a educação democrática, a esfera pública, a saída do senso comum, a superação dos dogmas do mercado e do fetiche da mercadoria, da arte e da cultura apenas como mercadoria e valor de troca dependem ainda de um trabalho crítico e seletivo, formativo e elaborado. Nem herdeiros do elitismo aristocrático, nem adeptos do populismo pós-moderno, ficamos com o campo aberto para pensar com cuidado e atenção a literatura, a fotografia, o cinema, o teatro, a pintura, a canção, o cordel, o carnaval, a escultura, a arquitetura, o artesanato, as artes gráficas, o desenho de humor, como expressões legítimas e variadas.

Daí não segue uma posição hostil à tecnologia, pois muito se pode aprender e fruir com a reprodução técnica. Não se trata, portanto, de fazer a defesa de uma espécie de esfera pública burguesa do século XIX, em que tudo devesse passar apenas pelo livro, pelo concerto, pelo museu e pelo espetáculo ao vivo. A reprodução técnica pode servir muito bem a uma educação crítica, dando acesso a formas culturais e estéticas antes restritas ao circuito fechado da elite. Isso vale para o livro, o filme, a fotografia, assim como para a música clássica e as gravações em disco, que permitem às gerações seguintes ouvirem e participarem de uma arte que, de outra forma, seria devorada pelo tempo e esquecida, na melhor das hipóteses lembrada pela via indireta dos comentários e registros escritos. São exemplos que vão na contracorrente dos simulacros de massa mais violentos e vulgares, atualizando o debate, sem defender uma impossível e indesejável volta a algum passado ideal que, de resto, nunca existiu de fato. Exceto, é claro, para minorias muito restritas e cultivadas. O que não se pode esquecer é que tal possibilidade depende de um projeto de poder que também vai na contracorrente da crise que vivemos no capitalismo avançado, indicando uma visão do espaço público, da democracia, da educação, da riqueza social, bem diferente dos simulacros de massa que formam a sociedade do espetáculo. Mais do que isso, defesa seletiva do acesso à arte e à cultura que não deve ser associada ao mofo das posi- 
ções elitistas, mas sim ao prazer, ao conhecimento e à percepção prazerosos, traços felizes, pontos de luz para além da vida na caverna pós-moderna. Nem se entenda que os árbitros do gosto seriam os filhos das classes médias urbanas e letradas, repetindo um erro dos mais primários e conhecidos, que é o de generalizar suas posições, como se fossem as de todo mundo. Na encruzilhada histórica recessiva e violenta em que estamos postos, não é possível dizer como seria uma outra forma de viver em sociedade, já que a crise afeta a todos, em maior ou menor escala. Sem ilusões, é possível que a crise se arraste ao longo de muitos anos, sem que a cegueira típica do capitalismo saia de cena.

Seja como for, a tarefa do pensamento crítico continua sendo denunciar as formas históricas violentas, que excluem a maioria e empobrecem a experiência, mutilam a vida, sem aderir aos consolos bem regressivos vendidos em massa. Em plena crise, o trabalho dos que deram forma a uma tradição crítica brasileira, pensando nosso lugar no mundo a partir de uma perspectiva realmente aberta e internacionalista, não pode ser deixado de lado como anacronismo, mas sim percebido como um poderoso ponto de apoio para tomar pé no presente e enxergar um pouco mais adiante. Ao contrário da paidéia pós-moderna, que confia na mão invisível do mercado para educar os cidadãos e organizar a vida.

\section{Nota}

1 Doutor em Teoria da Literatura pela Universidade Federal do Rio de Janeiro; Professor Adjunto da Faculdade de Letras, Universidade Federal do Rio de Janeiro e pesquisador do CNPq. 


\section{Referências}

ADORNO, Theodor; HORKHEIMER, Max. 1989. A dialética do esclarecimento. Rio de Janeiro: Zahar.

. 1974. La dialectique de la raison. Paris: Gallimard.

BENJAMIN, Walter. 1985. Obras escolhidas I- magia e técnica, arte e política. São Paulo: Brasiliense.

CANDIDO, Antonio. 1987. A educação pela noite e outros ensaios. São Paulo: Editora Ática.

CASTEL, Robert. 1999. As metamorfoses da questão social. Coleção Zero à Esquerda, Petrópolis: Vozes.

CHESNAIS, François. 1996. A mundialização do capital. São Paulo: Xamã.

DEBORD, Guy. 1997. A sociedade do espetáculo. Rio de Janeiro: Contraponto.

_. 1996. Commentaires sur la societé $d u$ spectacle. Paris: Gallimard.

_.1992. La societé du spectacle. Paris: Gallimard.

FIUZA, Alex de M. 2000. Capitalismo e mundialização em Marx. São Paulo: Editora Perspectiva.

FORRESTER, Viviane. 1997. O horror econômico. São Paulo: Editora Unesp.

FURTADO, Celso. 1992. A construção interrompida. Rio de Janeiro: Paz e Terra.

_.1982. A nova dependência. Rio de Janeiro: Paz e Terra.

_. 1999. O longo amanhecer - reflexões sobre a formação do Brasil. Rio de Janeiro: Paz e Terra.

HIRST, Paul; THOMPSON, Grahame. 1998. Globalização em questão. Petrópolis: Vozes, Coleção Zero à Esquerda.

JAMESON, Fredric. 1991. Postmodernism or the cultural logic of late capitalism. Durham: Duke University Press.

1996. Pós-modernismo - a lógica cultural do capitalismo tardio. Trad. Maria Elisa Cevasco e Iná Camargo Costa. São Paulo: Editora Ática.
JAY, Martin. 1977. L' imagination dialectique - L'école de Francfort, 1923-1950. Paris, Editions Payot.

MARINI, Ruy M. 2000, Dialética da dependência. Petrópolis: Vozes.

PLATÃo. A república. 1987. Lisboa: Fundação Calouste Gulbenkian.

POCHMANN, Marcio. 2001. O emprego na globalização - a nova divisão internacional do trabalho e os caminhos que o Brasil escolheu. São Paulo: Boitempo Editorial.

RAMONET, Ignacio. 2002. A colonização do ciberespaço. Le Monde Diplomatique, edição brasileira, janeiro. Editora Unesp, n. 3.

SAMPAIO Jr., Plínio de A. 1999. Entre a nação e a barbárie - os dilemas do capitalismo dependente. Petrópolis: Editora Vozes.

SARAMAGO, José. 1982. Memorial do convento. Lisboa: Editorial Caminho. 1984. O ano da morte de Ricardo Reis. Lisboa: Editorial Caminho. 1993. História do cerco de Lisboa. São Paulo: Cia das Letras. 1995. Ensaio sobre a cegueira. São Paulo: Cia das Letras. . 1997. Todos os nomes. São Paulo: Cia das Letras. 2000. A caverna. São Paulo: Cia das Letras.

SCHWARZ, Roberto.1987. Que horas são? São Paulo: Cia das Letras. 1999. Sequências brasileiras. São Paulo: Cia das Letras.

SNYDERS, Georges.1993. Alunos felizes reflexões sobre a alegria na escola a partir de textos literários. Rio de Janeiro: Paz e Terra.

WALLERSTEIN, Immanuel.1983. Historical capitalism. London: Verso. 2001. Capitalismo histórico e civilização capitalista. Rio de Janeiro: Contraponto. 